\title{
Yield and Quality of Vegetable Soybean Cultivars for Production in North Dakota
}

\author{
Lisa M. Duppong and Harlene Hatterman-Valenti
}

AdDitIONAL INDEX WORDs. edamame, irrigation, population

\begin{abstract}
Summary. Vegetable soybeans (Glycine max), the same species as field-dried soybeans, have similar production requirements and good market potential for commercial producers in upper midwestern United States. Five vegetable soybean cultivars were tested for yield and quality characteristics and to assess the necessity of field irrigation during 2003 and 2004 in North Dakota. Cultivars of different maturity dates were evaluated for stand densities, pod production, seed weight, and marketable yield. Total marketable yields varied between the years, ranging from 5773 to $10,118 \mathrm{lb} /$ acre. Lower yields in 2003 were attributed to significantly lower population stands caused by poor germination conditions. 'Envy', the earliest maturing cultivar, produced a significantly smaller seed size, while 'Sayamusume' produced a greater seed size than the other cultivars both years. 'Butterbean', 'IA1010', and 'IA2062' yielded greater percentages of threebean pods than the other two cultivars each growing season. Irrigation did not increase the marketable pod yield or the quality variables examined each season; thus it appears that rainfall during the growing season may be adequate for vegetable soybean production in this region.
\end{abstract}

A novel crop in upper midwestern U.S., vegetable soybeans have been eaten in China for over 2000 years. Also known as beer beans, sweet beans, edamame (Japanese), and mao dou (Chinese), this vegetable is quickly gaining popularity in the U.S. along with other soy foods and soy products. The beans are planted and cultivated in the same manner as field-dried soybeans, but they are harvested at an immature green stage (R6) that occurs just as the seeds have filled out the pod (Fehr et al., 1971). Vegetable soybean cultivars also have larger seeds than other field soybeans, a sweeter, nutty (less "beany") taste, and are more easily digested (Konovsky et al., 1994). They can be eaten fresh or used as a vegetable ingredient in stirfries, soups, and salads. These edible soybeans are considered a nutritious substitute for lima beans (Phaseolus limensis) in any dish (Konovsky et al., 1994), and they can also be boiled,

\footnotetext{
Department of Plant Sciences, North Dakota State University, 166 Loftsgard Hall, Fargo, ND 58105.

The authors wish to thank the Cooperative State Research, Education, and Extension Service, USDA, for their financial support of this research. Planting equipment and extra assistance from Burton Johnson, Paul Mayland, and Carrie Schumacher were greatly appreciated in this project. Mention of a trademark or proprietary product does not constitute endorsement or guarantee by North Dakota State University, and does not imply its approval to the exclusion of other similar products that may also be suitable.
}

frozen, or roasted and seasoned as a finger-food snack.

The sweet and savory taste of vegetable soybeans is attributed to their sucrose, glutamic acid, and alanine content (Johnson et al., 1999); they are a good source of protein, dietary fiber, vitamin $\mathrm{C}$ (ascorbic acid), vitamin $\mathrm{E}$ (tocopherol), calcium, and phytoestrogens (Johnson et al., 1999; Miles et al., 2000). Their demand is growing worldwide, most likely due to their tastiness and the known health benefits of soybean isoflavones. These include decreasing low-density lipoprotein (LDL) cholesterol levels and reducing the risk of cardiovascular diseases, cancer, and osteoporosis (Messina, 2001). By 2005, the U.S. demand for this vegetable is expected to exceed $\$ 20$ million annually, with greatest market potential among Asian Americans (Lin, 2001; Mentreddy et al., 2002). Nearly all the edamame crop grown in Japan is used for fresh consumption (Konovsky et al., 1994), and it is the largest importer of the crop with a total demand of more than 176,000 tons annually (Nguyen, 1998).

Only the beans are edible, although many Asian consumers prefer to purchase them intact in the slightly pubescent pods. Some even prefer to buy them still attached to freshly cut soybean plants at the market. The marketability of the beans depends on the customer; Asians prefer to purchase bright green pods (with no yellowing or discoloration) containing two to four beans, whereas typical American consumers purchase the frozen, shelled beans.

Vegetable soybean cultivars mature at different seasonal lengths based on their photoperiod sensitivity, possibly a limiting factor in their production in northern climates (Miles et al., 2000). Agronomic practices such as time of planting and harvesting, plant density, and soil fertilization may influence their flavor (Masuda, 1989). Other field production constraints include poor germination and slow emergence, and the need for fresh seed each growing season (Miles, 2002). Due to harvestable seed losses from severe pod shattering at maturity, the seed can be expensive at up to $\$ 22 / \mathrm{lb}$ (Nelson et al., 2002). Few insect and disease problems have been reported by U.S. researchers, although bacterial blight (Psendomonassyringaepv.glycinea) has been reported as a problem in irrigated research plots in Colorado (Johnson, 1999). Recommended seeding rates range between 60,000-70,000 plants / acre on the west and east coasts of the U.S. (Kratochvil, 2002; Miles et al., 2000 ) to 40,000 plants/acre in Missouri (Nelson et al., 2002).

Vegetable soybean production may be a viable option for farmers interested in a high-value crop with regional and local market potential in the midwestern U.S. Organic farmers especially may benefit if they choose to plant a high-value legume such as vegetable soybean in their crop rotation. Net returns of $\$ 350$ to $\$ 1125 /$ acre have been reported in other parts of

\begin{tabular}{llll}
\hline $\begin{array}{l}\text { Units } \\
\text { To convert U.S. to SI, } \\
\text { multiply by }\end{array}$ & U.S. unit & SI unit & $\begin{array}{l}\text { To convert SI to U.S., } \\
\text { multiply by }\end{array}$ \\
\hline 0.4047 & $\mathrm{acre}(\mathrm{s})$ & $\mathrm{ha}$ & 2.4711 \\
0.3048 & $\mathrm{ft}$ & $\mathrm{m}$ & 3.2808 \\
2.5400 & inch(es) & $\mathrm{cm}$ & 0.3937 \\
25.4000 & inch $(\mathrm{es})$ & $\mathrm{mm}$ & 0.0394 \\
1.1209 & $\mathrm{lb} / \mathrm{acre}$ & $\mathrm{kg} \cdot \mathrm{ha}^{-1}$ & 0.8922 \\
28.3495 & $\mathrm{Oz}$ & $\mathrm{g}$ & 0.0353 \\
$\left({ }^{\circ} \mathrm{F}-32\right) \div 1.8$ & ${ }^{\circ} \mathrm{F}$ & ${ }^{\circ} \mathrm{C}$ & $\left(1.8 \times{ }^{\circ} \mathrm{C}\right)+32$
\end{tabular}


the U.S. (Ernst and McNulty, 2001), and sales are expected to rise with increasing consumer awareness of soy health benefits, its versatility, and ease in cooking. Currently there are no known edamame producers in North Dakota, probably due to a lack of information on yield performance of specific cultivars grown in the northern Great Plains region, subsequent marketing analyses, and processing infrastructure for the crop. Moreover, one of only two vegetable soybean processors in the U.S. is located within the region (Hearty \& Natural, Hope, Minn.). Their frozen shelled and unshelled "sweet soybeans" and "edamames" are sold in local and national health food and supermarket chains. Based on a $15 \%$ growth in retail sales during the past year, they are expanding their production acreage by $20 \%$ in 2005 ( $R$. Staloch, personal communication).

The objective of this 2-year research project was to evaluate five vegetable soybean cultivars in North Dakota for agronomic performance and quality traits. Production variables examined included stand establishment, number of pods/plant, total marketable yields, and fresh green seed weight. Cultivar response to irrigation during the growing season was also assessed. Irrigation has been recommended for vegetable soybean production in Washington, which receives 2 to 6 inches of precipitation between May and September (Miles et al., 2000). Rainfall amounts in eastern North Dakota average almost twice this amount (14.2 inches in the past 10 years) between May and September (North Dakota Agricultural Weather Network, 2004). The climate is less arid, and elimination of an additional expense, such as irrigation, would make vegetable soybeans a more viable production option for growers in the northern Great Plains.

\section{Materials and methods}

Five vegetable soybean cultivars were evaluated during 2003 and 2004 at the North Dakota State University (NDSU) Experiment Site near Prosper, N.Dak. (lat. $47^{\circ} 00^{\prime} \mathrm{N}$, long. $\left.97^{\circ} 07^{\prime} \mathrm{W}\right)$. The soil is a Bearden silty clay (fine-silty, mixed, superactive, frigid Aeric Calciaquoll) with a $3.6 \%$ organic matter content and a $7.5 \mathrm{pH}$. Each year the previous crop was spring wheat (Triticum aestioum). The field was disked in the fall after harvest and cultivated in the spring prior to planting. Plots were arranged in a split-plot design with four replicates. Main plots were two irrigation schedules (irrigation vs. no irrigation) while the subplots were five soybean cultivars: 'Envy', 'Butterbean' (Johnny's Selected Seeds, Albion, Maine), 'IA1010', 'IA2062' (Iowa State Univ., Ames), and 'Sayamusume' (Territorial Seed Company, Cottage Grove, Ore.). An experimental unit consisted of four 20 -ft-long rows spaced 24 inches apart. Data were taken from the two middle rows.

Cultivars were planted 7 June 2003 and 11 June 2004. The seed was planted at a depth of 1.25 inches using a four-row Almaco cone seeder (Nevada, Iowa); the seeding rate was adjusted for a target population of 100,000 plants/acre. The plots were hand-weeded once during July and August each year. Stand counts on both rows were taken 17 July 2003 and 23 July 2004. The overhead irrigation system had risers spaced $18 \mathrm{ft}$ apart; water was applied at $1 \mathrm{inch} /$ week to supplement natural rainfall. Irrigation was scheduled according to calculations using the NDSU Extension Service recommendations for the checkbook method guidelines with soybean as the crop (Steele et al., 2004). It was applied 3 weeks in 2003 (21 July, 31 July, and 16 Aug.) and 5 weeks in 2004 (2 July, 16 July, 28 July, 6 Aug., and 18 Aug.). Plots were hand-harvested at the R6 stage, when the bright green bean seeds were touching each other in a pod on an upper node of five sampled plants. The aboveground biomass was collected from $10 \mathrm{ft}$ of the two middle rows. All pods were removed from the plants, with marketable pods separated into categories of one-bean, two-bean, and three-bean pods. Fresh unshelled weights were obtained for each category. Additional data included counting the number of pods on each of three randomly selected plants per plot, and obtaining fresh weights for 100 shelled seeds of three subsamples per plot. Harvest dates for each growing season were as follows: 2003 : 'Envy', 5 Sept.; 'Butterbean' and 'Sayamusume', 12 Sept.; 'IAl010' and 'IA2062', 23 Sept.; and 2004: 'Envy', 7 Sept.; 'Sayamusume', 13 Sept.; 'Butterbean', 17 Sept.; 'IA1010' and 'IA2062', 28 Sept. Data sets were combined for the 2 years and analyzed using analysis of variance (PROC GLM) with SAS version 8.2 (SAS Institute, Cary, N.C.). Factors were considered fixed. Based on interactions between variables, means were separated by Fisher's protected least significant difference (LSD) test where $P=0.05$.

\section{Results}

A significant year $\times$ cultivar interaction occurred; therefore population stand, total marketable yield, pods/plant, and seed weight means were separated and analyzed by year (Table 1). Furthermore, a significant year $\times$ irrigation $\times$ cultivar interaction occurred in the number of beans/pod;

Table 1. Analysis of variance testing the effects of year, irrigation, and cultivar on vegetable soybean production variables, including stand, total marketable yield, pods/plant, seed weight, and percentage of one-bean, two-bean, and three-bean pods for 2003 and 2004 at Prosper, N. Dak.

\begin{tabular}{|c|c|c|c|c|c|c|c|c|}
\hline Source & df & Stand & Yield & Pod/plant & Seed wt & One-bean & Two-bean & Three-bean \\
\hline Rep & 3 & 0.8687 & 0.3333 & 0.6432 & 0.0243 & 0.4258 & 0.2290 & 0.0715 \\
\hline Irrigation (I) (rep) & 3 & 0.1392 & 0.1922 & 0.8258 & 0.3141 & 0.3600 & 0.3866 & 0.8738 \\
\hline $\mathrm{Y} \times \mathrm{I}$ & 1 & 0.0245 & 0.1366 & 0.8282 & 0.0079 & $<0.0001$ & 0.0546 & $<0.0001$ \\
\hline Cultivar (C) & 4 & $<0.0001$ & $<0.0001$ & $<0.0001$ & $<0.0001$ & $<0.0001$ & $<0.0001$ & $<0.0001$ \\
\hline $\mathrm{I} \times \mathrm{C}$ & 4 & 0.1264 & 0.0248 & 0.456 & 0.1382 & 0.1693 & 0.1152 & 0.5033 \\
\hline $\mathrm{Y} \times \mathrm{I} \times \mathrm{C}$ & 4 & 0.8702 & 0.7069 & 0.7638 & 0.5228 & 0.0272 & 0.6081 & 0.5245 \\
\hline
\end{tabular}


Table 2. Rainfall and temperature data ${ }^{\mathrm{z}}$ for the 2003 and 2004 growing seasons and 10-year averages at Prosper, N. Dak.

\begin{tabular}{lccccc}
\hline & \multicolumn{2}{c}{ Total precipitation (inches) } & & \multicolumn{2}{c}{ Average air temp $\left({ }^{\circ} \mathbf{F}\right)^{\mathrm{x}}$} \\
\cline { 2 - 3 } \cline { 5 - 6 } Year & 30 DAP & Season & & Daily maximum & Season \\
\hline 2003 & 3.95 & 6.46 & & 80 & 67 \\
2004 & 2.04 & 8.19 & & 74 & 62 \\
l0 $^{\text {year }}{ }^{\mathrm{w}}$ & 4.03 & 8.94 & & 76 & 64 \\
\hline
\end{tabular}

${ }^{2}$ Data provided by North Dakota Agricultural Weather Network, Department of Soil Science, North Dakota State University, Fargo.

${ }^{y} \mathrm{l}$ inch $=0.0394 \mathrm{~mm} ; \mathrm{DAP}=$ days after planting; season totals from 11 June to 23 Sept. 2003 and 7 June to 28 Sept. 2004.

$\times\left({ }^{\circ} \mathrm{F}-32\right) / 1.8={ }^{\circ} \mathrm{C}$; daily maximum values represent averages of greatest daily temperature measurements; season values represent average temperature measurements [(high-low)/2] calculated daily.

"10-year values averaged from 1994-2004 during 7 June to 11 July for 30 DAP average and 7 June to 28 Sept. for remaining columns.

thus, means for one-bean, two-bean, and three-bean pod percentages were analyzed for this three-way interaction.

All cultivars reached sufficient maturity during both growing seasons. Average harvest date for all cultivars was 7.6 d later in 2004 than 2003, most likely due to cooler air temperatures throughout the 2004 growing season (Table 2). Natural precipitation received $30 \mathrm{~d}$ after planting in 2003 was similar to the 10 -year average, totaling 3.95 inches, although the rains were untimely and heavy. Cool weather and overly damp conditions after planting in 2003 most likely contributed to poor population stands (Table 3 ). By comparison, the drier conditions in the early part of 2004 (2.04 inches) may have been conducive to the greater and more uniform stands. Irrigation was less necessary in 2003, as it was applied fewer times and later in the season than in 2004 . The heavy clay soil in that area most likely aided water retention throughout the season. Moreover, close row spacing of the plants (typically field-dried soybean rows are planted 30 inches apart) allowed for early crop canopy and less water loss due to surface evaporation.
Significant differences were detected among the cultivars and between growing seasons for most experimental variables (Table 3 ). Despite the poor weather early in the 2003 growing season, 'Envy' and 'IA2062' had significantly greater stands compared to the other cultivars. Stands were much higher in 2004, and the range between population means was smaller. Total marketable yields were fairly similar in 2003. 'Butterbean' yielded less than the other cultivars that year and displayed the greatest difference in yield between the first and second year. This was attributed to it having the lowest population stand in 2003 , and the greatest difference between stands each season $(55,947$ plants/acre). In 2004, 'Envy' yielded less than the other cultivars, averaging 26\% less than the highest yielding cultivar, 'Sayamusume'. Moreover, 'Sayamusume' produced the greatest yield from the lowest population stand that year. Based on stands, individual plant yields were lower in 2004 for all cultivars, most likely because of overall cooler seasonal air temperatures in 2004 (which averaged $5^{\circ} \mathrm{F}$ cooler than in 2003) and the increased competition between soybean plants caused by higher population densities.

Each cultivar produced approximately twice as many pods / plant in the first growing season than in the second (Table 3), suggesting that field population densities and weather conditions may also have affected the number of pods/plant. 'Envy' produced the highest number of pods/plant both years in more dense population stands than most or all the other cultivars. 'Sayamusume', on the other hand, had the least number of pods/plant even though it had two of the lowest populations both years. Seed weight comparisons for all cultivars between growing seasons showed that only 'Sayamusume' produced smaller seeds in 2004. Pod set appeared inversely related to seed size $(r=-0.6299$ and -0.9807 in 2003 and 2004, respectively), since 'Sayamusume' fresh seed weight was greater than other cultivars, while 'Envy' produced significantly smaller seeds. However, these factors are also influenced genetically and environmentally, since the decrease in number of pods produced by the cultivars in 2004 did not reflect the same increase in seed weight, especially with 'Sayamusume'. Individual seed growth has been shown to be dependent on the amount of available assimilates during seed filling with field soybean (Munier-Jolain et al., 1994). Likewise, Mathew et al. (2000) concluded that even though maximum soybean seed size is under genetic control, seed size can be modified by the environment with some internal moderation of final size of most seeds in all pods. Rao et al. (2002) evaluated several Asian and two U.S.-adapted vegetable soybean cultivars and concluded that larger seed size was positively correlated with longer time periods to the R6 stage of maturity, and that fresh seed

Table 3. Stand, total marketable yield, pods/plant, and seed weight of hand-harvested vegetable soybean cultivars in 2003 and 2004 at Prosper, N.Dak.

\begin{tabular}{|c|c|c|c|c|c|c|c|c|}
\hline \multirow[b]{2}{*}{ Cultivar } & \multicolumn{2}{|c|}{$\begin{array}{c}\text { Stand } \\
(\text { plants } / \text { acre })^{\mathrm{z}}\end{array}$} & \multicolumn{2}{|c|}{$\begin{array}{l}\text { Marketable yield } \\
(\mathrm{lb} / \mathrm{acre})^{\mathrm{y}}\end{array}$} & \multicolumn{2}{|c|}{$\begin{array}{c}\text { Pods } \\
\text { (no./plant) }\end{array}$} & \multicolumn{2}{|c|}{$\begin{array}{c}\text { Seed wt } \\
(\mathrm{oz} / 100 \text { seeds })^{\mathrm{x}}\end{array}$} \\
\hline & 2003 & 2004 & 2003 & 2004 & 2003 & 2004 & 2003 & 2004 \\
\hline Envy & 50,230 a & 81,811 a & 7786 a & $7502 \mathrm{c}$ & $81.3 \mathrm{a}$ & 39.7 a & $1.36 \mathrm{c}$ & $1.46 \mathrm{~d}$ \\
\hline IA1010 & $29,471 \mathrm{~b}$ & $81,675 \mathrm{a}$ & $8213 \mathrm{a}$ & $9024 \mathrm{~b}$ & $74.1 \mathrm{a}$ & $36.4 \mathrm{ab}$ & $1.60 \mathrm{~b}$ & $1.67 \mathrm{c}$ \\
\hline IA2062 & $55,471 \mathrm{a}$ & $79,293 \mathrm{ab}$ & $8722 \mathrm{a}$ & $8675 \mathrm{~b}$ & $54.6 \mathrm{~b}$ & $33.5 \mathrm{~b}$ & $1.55 \mathrm{~b}$ & $1.76 \mathrm{bc}$ \\
\hline
\end{tabular}

${ }^{\mathrm{z}} 1 \mathrm{plant} /$ acre $=2.4711$ plants $/ \mathrm{ha}$

y $1 \mathrm{lb} /$ acre $=0.8922 \mathrm{~kg} \cdot \mathrm{ha}^{-1}$.

${ }^{\mathrm{x}} \mathrm{loz} / 100$ seeds $=3527.4$ seeds $/ \mathrm{kg}$.

within a column, means followed by the same letter are not significantly different with Fisher's protected least significant difference at $P=0.05$. 
Table 4. Percentage of one-bean (1-bean), two-bean (2-bean), and three-bean (3-bean) pods of total marketable yield for hand-harvested vegetable soybean cultivars based on supplemental irrigation (IRR) [ 1 inch $(25.4 \mathrm{~mm})$ per week] and no irrigation (NON) in 2003 and 2004 at Prosper, N. Dak.

\begin{tabular}{|c|c|c|c|c|c|c|c|c|c|c|c|c|}
\hline \multirow[b]{3}{*}{ Cultivar } & \multicolumn{6}{|c|}{2003} & \multicolumn{6}{|c|}{2004} \\
\hline & \multicolumn{3}{|c|}{ IRR } & \multicolumn{3}{|c|}{ NON } & \multicolumn{3}{|c|}{ IRR } & \multicolumn{3}{|c|}{ NON } \\
\hline & 1-bean & 2-bean & 3-bean & 1-bean & 2-bean & 3-bean & 1-bean & 2-bean & 3-bean & 1-bean & 2-bean & 3-bean \\
\hline Butterbean & $8.0 c^{z, y}$ & $59.0 \mathrm{c}$ & $33.0 \mathrm{a}$ & $11.8 \mathrm{c}$ & $62.7 b$ & $25.5 b$ & 16.6 & $53.4 \mathrm{c}$ & $30.0 \mathrm{a}$ & $12.0 \mathrm{~b}$ & $53.7 \mathrm{c}$ & $34.3 \mathrm{a}$ \\
\hline Envy & $17.5 \mathrm{a}$ & $75.9 a$ & $6.6 c$ & $20.1 \mathrm{a}$ & $75.4 \mathrm{a}$ & $4.0 \mathrm{~d}$ & 15.3 & $76.8 \mathrm{a}$ & $7.9 \mathrm{c}$ & $16.9 \mathrm{a}$ & $72.0 \mathrm{a}$ & $11.2 \mathrm{~d}$ \\
\hline IA1010 & $8.8 \mathrm{bc}$ & $51.9 \mathrm{~d}$ & $39.3 \mathrm{a}$ & $9.6 \mathrm{~d}$ & $54.3 \mathrm{c}$ & $36.1 \mathrm{a}$ & 16 & $53.4 \mathrm{c}$ & $30.6 a$ & $13.6 \mathrm{~b}$ & $53.4 \mathrm{c}$ & $33.0 \mathrm{ab}$ \\
\hline
\end{tabular}

${ }^{2}$ Values represent percentage of unshelled mean weights.

Within a column, means followed by the same letter or not followed by a letter are not significantly different with Fisher's protected least significant difference at $P=0.05$.

weight varied inversely with pod set and seeds per pod. The harvest dates for 'IA1010' and 'IA2062' were later than 'Sayamusume' for both years, yet each produced smaller seeds. Thus, genotype appears to have a strong influence on this variable, as later-maturing cultivars do not necessarily produce heavier seeds.

Number of seeds per pod is not known to affect bean flavor or quality (Miles et al., 2000). However, it is an important variable to consider for fresh market production, since many Asian consumers prefer two-bean and three-bean pods. Seeds per pod varied among cultivars and between years $(P$ $=0.05)$. 'Envy' produced more onebean pods and fewer three-bean pods than the other cultivars both seasons (Table 4). There was also a tendency for higher yields of one-bean pods in non-irrigated than irrigated plots in 2003 , although not statistically different at $P=0.05$. This response may have been caused by stress associated with decreased rainfall and increased temperatures during pod set that year. In 2004, the reverse was true with higher yields of one-bean pods in the irrigated than non-irrigated plots, with the exception of 'Envy'. There were no significant differences between irrigated and non-irrigated percentages of two-bean pods among cultivars for either growing season. Each year 'Envy' produced a significantly higher percentage of two-bean pods than the other cultivars, followed by 'Sayamusume'. Significantly higher percentages of three-bean pods were found in 'IA1010', 'IA2062', and 'Butterbean' than the other two cultivars both growing seasons. The percentages of three-bean pods were significantly higher in irrigated plots of 'Butterbean' in 2003 compared to non-irrigated plots. 'Sayamusume' had lower three-bean pod percentages than most cultivars for both years; this suggests that its heavier marketable yield in 2004 was most likely due to its heavier seed weight.

These five vegetable soybean cultivars have potential to perform well under North Dakota growing conditions. Collectively they offer a range of green pod harvest dates that could allow producers to extend their harvest season and increase yields. Though it has a small seed size and a high number of one-bean pods, 'Envy' may be attractive for growers who are interested in an early maturing cultivar. In addition to maturing later, 'IA1010', 'IA2062', and 'Butterbean' may be more desirable cultivars for producers who are interested in greater yields of three-bean pods for fresh market consumption. The large seed size of 'Sayamusume' is a distinct characteristic that may make this cultivar more attractive to some consumers.

Vegetable soybean yields will vary based upon cultivars, weather conditions such as seasonal rainfall and air temperature, and cultural practices such as plant population and irrigation. In southeastern North Dakota, irrigation may only be warranted for production in excessively dry years, especially during the reproductive stages of plant development. Further investigation to determine optimum plant populations for different cultivars are needed. Consumer preferences on taste and nutritional content should also be assessed for all cultivars before making grower recommendations. Commercial production is currently constrained by a lack of mechanical harvesting equipment. Moreover, the harvest window is short for vegetable soybean, and immediate processing is necessary to preserve bean quality and flavor. These obstacles are not insurmountable for growers, however, as has been proven by the Hearty \& Natural ${ }^{\mathrm{TM}}$ cooperative of vegetable soybean producers in southern Minnesota.

\section{Literature cited}

Ernst, M. and S. McNulty. 2001. Green edible soybeans: Marketing new crops. Univ. of Ky. Dept. of Agr. Econ., Lexington. 7 Mar. 2005. <http://www.uky.edu/Ag/ NewCrops/soybeanmarketing.pdf $>$.

Fehr, W.R., C.E. Caviness, D.T. Burmood, and J.S. Pennington. 1971. Stage of development descriptions for soybeans, Glycine $\max ($ L.) Merrill. Crop Sci. 11:929-931.

Johnson, D. 1999. Market improving for edamame. Agron. News 19:1 Coop. Ext. Colo. State Univ., Fort Collins. 7 Mar. 2005. <http://www.colostate.edu/ Depts/SoilCrop/extension/Newsletters/1999/JAN99.PDF>.

Johnson, D., S. Want, and A. Suzuki. 1999. Edamame: A vegetable soybean for Colorado, p. 385-387. In: J. Janick (ed.). Perspectives on new crops and new uses. ASHS Press, Alexandria, Va.

Konovsky, J., T.A. Lumpkin, and D. McClary. 1994. Edamame: The vegetable soybean, p. 173-181. In: A.D. O'Rourke (ed.). Understanding the Japanese food and agrimarket: A multifaceted opportunity. Haworth Press, Binghamton, N.Y.

Kratochvil, R. 2002. Edible soybean variety evaluations. Univ. of Md., College Park. 12 Dec. 2004. <http://www.nrsl. umd.edu/extension/crops/soybeans / 200 lediblesoybean.pdf $>$.

Lin, C-C. 2001. Frozen edamame: Global market conditions, p. 93-96. In: T.A. Lumpkin and S. Shanmugasundaram (eds.). 2nd Intl. Veg. Soybean Conf. Wash. State Univ., Pullman.

Masuda, R. 1989. Yasai no reito-Edamame. Refrigeration 64:359-376. 
Mathew, J.P., S.J. Herbert, S. Zhang, A.F. Rautenkranz-Andreas, and G.V. Klitchfield. 2000. Differential response of soybean yield components to the timing of light enrichment. Agron. J. 92:1156-1161.

Mentreddy, S.R., A.I. Mohamed, N. Joshee, and A.K. Yadav. 2002. Edamame: A nutritious vegetable crop. p. 432-438. In: J. Janick and A. Whipkey (eds.). Trends in new crops and new uses. ASHS Press, Alexandria, Va.

Messina, M. 2001. An overview of the health effects of soyfood and soybean isoflavones. p. 117-122. In: T.A. Lumpkin and S. Shanmugasundaram (eds.). 2nd Intl. Veg. Soybean Conf. Wash. State Univ., Pullman.

Miles, C.A. 2002. Edamame variety trial. Coop. Ext. Wash. State Univ., Vancouver. 7 Mar. 2005. <http://agsyst.wsu.edu/ EDVarietyReport2001.pdf $>$.

Miles, C.A., T.A. Lumpkin, and L. Zenz. 2000. Edamame. Food \& farm connection. Wash. State Univ. Coop. Ext. Pacific Northwest Ext. Publ. PNW0525.

Munier-Jolain, N.G., B. Ney, and C. Duthion. 1994. Reproductive development of an indeterminate soybean as affected by morphological position. Crop Sci. 34:1009-1013.

North Dakota Agriculture Weather Network. 2004. Dept. Soil Science. N.Dak. State Univ., Fargo. 18 Nov. 2004. <http: www.ndawn.ndsu.nodak.edu/>.

Nelson, K., R. Smoot, and D. Harder. 2002. Edamame soybean summary (SOY1101). Mo. Agr. Expt. Sta., Univ. of Missouri, Columbia. 7 Mar. 2005. <http://aes.missouri. edu/greenley/research/soyl101.stm>.

Nguyen, V.Q. 1998. Edamame (vegetable green soybean), p. 196-203. In: The new rural industries: A handbook for farmers and investors. Rural Ind. Res. \& Dev. Corp., Canberra. 7 Mar. 2005. <http://www. rirdc.gov.au/pub/handbook/edamame. html>.

Rao, M.S.S., A.S. Bhagsari, and A.I. Mohamed. 2002. Fresh green seed yield and seed nutritional traits of vegetable soybean genotypes. Crop Sci. 42:1950-1958.

Steele, D.D., T.F. Scherer, N. Pederson, and J. Wright. 2004. Computerized irrigation scheduling by the checkbook method: Spreadsheet edition for North Dakota and Minnesota, Version 2.01. N.Dak. State Univ. Ext. Serv., Fargo, Univ. Minn. Ext. Serv. Minneapolis. Publ. AE792. 